\title{
A Comparison of Return Bloom and Nonstructural Carbohydrates, Nitrogen, and Potassium Concentrations in Moderate and Severe Alternate-bearing Pecan Cultivars
}

\author{
Charles T. Rohla ${ }^{1}$, Michael W. Smith ${ }^{2,5}$, and Niels O. Maness ${ }^{3}$ \\ Department of Horticulture \& Landscape Architecture, Oklahoma State University, Stillwater, \\ OK 74078 \\ William Reid ${ }^{4}$ \\ Pecan Experiment Field, Kansas State University, Chetopa, KS 67336 \\ AdDitional INDEX words. Carya illinoinensis, fruit, flower, flowering, irregular bearing
}

\begin{abstract}
The most significant horticultural problem facing pecan producers is alternate bearing. Four pecan [Carya illinoinensis (Wangenh.) C. Koch] cultivars were chosen, two with low to moderate and two with severe alternatebearing tendencies, to compare selected characteristics related to irregular bearing. The cultivars were Colby and Peruque (low to medium alternate-bearing tendency) and Osage and Giles (high alternate-bearing tendency). Vegetative shoots and fruit-bearing shoots in the terminal and lateral position on 1-year-old branches were tagged in October, and flowering was determined the next spring. Shoot and root samples were collected while dormant and then analyzed for organically bound nitrogen (N), potassium (K), and nonstructural carbohydrate concentrations. As expected, 'Colby' and 'Peruque' had a lower alternate-bearing tendency than 'Giles' and 'Osage'. Cultivars with a low alternate-bearing tendency had a larger return bloom on the bearing shoots in the terminal position than the other shoot types. Cultivars with a high alternate-bearing tendency had a lower return bloom on bearing terminal shoots than vegetative shoots. Bearing shoots in the lateral position usually had a lower return bloom than the other shoot types regardless of cultivar. Neither root nor shoot $\mathrm{N}$, $\mathrm{K}$, or nonstructural carbohydrate concentrations appeared to be closely related to the alternate-bearing characteristics of the four cultivars. The unique characteristic identified for low alternate-bearing cultivars was their ability to produce as many or more flowers and flowering shoots the next year on previously bearing terminal shoots compared with previously vegetative shoots. In high alternate-bearing cultivars, return bloom of bearing terminal shoots was suppressed relative to their vegetative shoots.
\end{abstract}

Alternate bearing is the most significant horticultural problem facing pecan producers. Studies have suggested that stored carbohydrate concentrations during the winter markedly affected subsequent flowering (Malstrom, 1974; Smith and Waugh, 1938; Wood, 1989, 1991; Worley, 1979a, 1979b). Other work suggested that the inhibition of return bloom by developing fruit was incited by phytohormones or other growth regulators (Amling and Amling, 1983; Smith et al., 1986; Wood, 2003; Wood and McMeans, 1981; Wood et al., 2003). Hypotheses for alternate bearing have undergone modification as more data became available. The current theory supports a two-level control with inhibitors and promoters determining induction during the previous growing season and the dormant season nonstructural carbohydrate pool influencing pistillate flower development (Smith et al., 1986; Sparks, 2000, 2003; Wood, 2003; Wood and McMeans, 1981; Wood et al., 2003).

Received for publication 10 Aug. 2006. Accepted for publication 11 Jan. 2007. Approved for publication by the Oklahoma Agricultural Experiment Station. Funding for this study was provided by the Oklahoma Agricultural Experiment Station, USDA Crop Germplasm Committee, Samuel Roberts Noble Foundation, and the Oklahoma Pecan Growers' Association.

${ }^{1}$ Former graduate student. Current address: Samuel Roberts Noble Foundation, Ardmore, Oklahoma 73402.

${ }^{2}$ Regents Professor

${ }^{3}$ Professor.

${ }^{4}$ Associate Professor.

${ }^{5}$ Corresponding author. E-mail: mike.smith@okstate.edu
Limited data suggested that cultivars with early fruit ripening had a lower alternate-bearing tendency than lateripening cultivars (Smith et al., 1986). However, an extensive study found no association between alternate-bearing intensity and fruit ripening date or nut volume (Wood et al., 2003). In addition, as the postripening foliation period increased, alternate bearing increased. Some cultivars with early-season fruit maturation such as 'Osage' exhibit strong alternate bearing in the northern locations and only moderate alternate bearing in southern areas with a longer growing season (Conner and Worley, 2000). 'Desirable', a late-ripening cultivar, has a low alternate-bearing tendency (Conner and Worley, 2000). These findings place doubt on the role of dormant season carbohydrate reserves in alternate bearing.

Nitrogen depletion by large crops occurs in pistachio (Pistacia vera L.) (Brown et al., 1995; Rosecrance et al., 1998; Weinbaum et al., 1994) and has been proposed to contribute to pecan alternate bearing (Goff et al., 2001; Kraimer et al., 2004; Wood, 2001). In pistachio, stored nitrogen during the winter was closely associated with the "on" and "off" bearing cycles (Picchioni et al., 1997; Rosecrance et al., 1996). Storage protein accounted for most of the nitrogen used during the initial spring growth flush and flowering in pistachio (Weinbaum et al., 1994). In pecan, stored $\mathrm{N}$ is preferentially used in the spring followed by rapid nitrogen $(\mathrm{N})$ absorption (Acuña-Maldonado et al., 2003). The amounts of stored versus 
absorbed N were inversely related. Kraimer et al. (2004) reported a late-season $\mathrm{N}$ application was rapidly absorbed, increasing stored $\mathrm{N}$. They speculated that increased stored $\mathrm{N}$ might moderate pecan alternate bearing.

Potassium is essential for photosynthesis, carbohydrate and protein synthesis, and enzyme activation (Marschner, 1995). Nonstructural carbohydrates and organically bound $\mathrm{N}$ must be transported from a source or storage site (net exporter) to a sink (net importer) through the phloem. Potassium availability affects both phloem loading and phloem transport (Haeder, 1977; Vreugdenhil, 1985) and consequently fruit development and yield. Potassium was rapidly transported to fruit as they neared maturity (Diver and Smith, 1984). Kernel oil content was closely correlated to leaf potassium concentration (Hunter and Hammer, 1956).

The objectives of this study were to determine certain characteristics of cultivars with low and high alternate-bearing tendencies. Specifically, return bloom characteristics of vegetative and bearing shoots and dormant season pools of nonstructural carbohydrates, potassium $(\mathrm{K})$, and organically bound $\mathrm{N}$ were ascertained to elucidate differences that might be useful in early selection of genotypes with less alternate-bearing tendencies and to increase understanding of the underlying causes of alternate bearing.

\section{Materials and Methods}

Four cultivars, located at the Kansas Pecan Experiment Field, near Chetopa, Kans., were chosen in 2001 based on their alternate-bearing tendency. The cultivars selected to represent a low to medium alternate-bearing intensity were 'Colby' and 'Peruque' and those chosen with a high alternate-bearing intensity were 'Osage' and 'Giles' (W. Reid, unpublished data). Typical ripening dates (50\% shuck split) for these cultivars at Chetopa are 18 Sept., 23 Sept., 25 Sept., and 15 Oct. for 'Osage', 'Peruque', 'Colby', and 'Giles', respectively. Trees were 20 years old and had similar crop loads (60\% to $70 \%$ bearing shoots) at the beginning of the study. Trees were growing in an Osage silty clay (fine, smectitic, thermic Typic Epiaquerts) and spaced $12.2 \times 12.2 \mathrm{~m}$ apart. Trunk diameter when the study was initiated was $20.8 \pm 3.0 \mathrm{~cm}$ measured $1.4 \mathrm{~m}$ above the ground. Nitrogen was surface-applied annually in March at $112 \mathrm{~kg} \cdot \mathrm{ha}^{-1} \mathrm{~N}$ from urea. Trees were not irrigated. Rainfall (1 Oct. through 30 Sept. rainfall year) was 925, 999, 753, and $990 \mathrm{~mm}$ during 2001, 2002, 2003, and 2004, respectively. Pest control followed standard commercial practices.

Shoot types were: 1) vegetative shoots, 2) fruit-bearing shoots in the terminal position on 1-year-old branches, and 3) fruit-bearing shoots in the lateral position on 1-year-old branches. Thirty shoots of each shoot type per tree were tagged at shuck split to monitor return bloom. Shoots were selected at random throughout the canopy. The next spring, the number of dead 1-year-old branches, new shoots per 1-year-old branch, flowers per cluster, and number of current season's shoots with female flower clusters were determined. Total yield per tree was measured annually and the alternate-bearing index $(I)$ was calculated (Pearce and Dobersek-Urbanc, 1967) for each cultivar. Values of this index range for 0 to 1 with 0 indicating no alternate bearing and 1 complete alternate bearing (no crop on alternate years).

In January, while trees were dormant, root and shoot samples were collected. Roots were separated into samples of less than
$1 \mathrm{~cm}$ and $1 \mathrm{~cm}$ or greater in diameter and then washed in tap water to remove adhering soil. The three shoot types described earlier were collected from the canopy periphery. Both roots and shoots were stored at $0^{\circ} \mathrm{C}$ until they were freeze-dried to a constant weight. Samples were then ground in a Wiley mill to pass through a 20-mesh screen and then stored in an airtight glass jar at $0{ }^{\circ} \mathrm{C}$ until analyzed. Organically bound $\mathrm{N}$ was analyzed by the macro-Kjeldahl method (Horowitz, 1980) and $\mathrm{K}$ was analyzed using atomic absorption spectroscopy. Nonstructural carbohydrate concentrations (starch, reducing and nonreducing sugars) were determined using Nelson's modification of Somogyi's method (Hodge and Hofreiter, 1962) that has been used for nonstructural carbohydrate determination in pecan tissue (Smith et al., 1986; Wood, 1984, 1989).

The experimental design was completely randomized with five single-tree replications per treatment (cultivar) for the variables yield, nut size, kernel yield, and root carbohydrate, $\mathrm{N}$, and $\mathrm{K}$ concentration. When return bloom and shoot carbohydrate, $\mathrm{N}$, or $\mathrm{K}$ concentration were analyzed, the influence of shoot type was nested within cultivar and 30 shoots of each shoot type served as subsamples. Main effects and interactions were tested using analysis of variance with mean separation by the protected least significant difference.

\section{Results}

Cultivars predicted to have a high alternate-bearing index ('Giles' and 'Osage') showed extreme differences among years in total production and had a higher alternate-bearing index than those cultivars selected to have a low alternate-bearing tendency (Table 1). 'Giles' had the greatest alternate-bearing intensity with a 50-fold difference between the high and low production years. 'Osage' had a threefold difference in the high and low year yields. Total production of 'Peruque' (low alternate-bearing index) was similar in 2001 and 2002 but was $32 \%$ higher in 2003 than the previous years. The alternatebearing index of 'Peruque', based on 3-year data, was the lowest of the cultivars included in this study, which agrees with earlier observations (W. Reid, unpublished data). The alternate-bearing index of 'Colby' was higher than 'Peruque' but substantially lower than 'Giles' or 'Osage'. Cumulative production of 'Peruque' and 'Osage' was similar followed by 'Colby' then 'Giles'. The ranking of cumulative yields agrees with long-term observations (W. Reid, unpublished data) for 'Peruque', 'Osage', and 'Colby', but underrepresents 'Giles', probably because 2 of the 3 years were "off' years for 'Giles'.

Shoot survival was similar among cultivars, shoot types, and years, averaging over 98\% survival (data not shown).

Table 1. Yield and alternate bearing index of four pecan cultivars.

\begin{tabular}{lrrrrc}
\hline & \multicolumn{4}{c}{ Yield \pm standard deviation $(\mathrm{kg} /$ tree $)$} & \multirow{2}{*}{$\begin{array}{c}\text { Alternate } \\
\text { bearing }\end{array}$} \\
\cline { 2 - 5 } Cultivar & \multicolumn{1}{c}{2001} & \multicolumn{1}{c}{2002} & \multicolumn{1}{c}{2003} & Cumulative & index $(I)^{\mathrm{z}}$ \\
\hline Colby & $8.5 \pm 6.5$ & $6.5 \pm 3.9$ & $3.6 \pm 3.3$ & $18.6 \pm 11.1$ & 0.21 \\
Peruque & $9.0 \pm 5.6$ & $8.7 \pm 5.9$ & $11.5 \pm 7.1$ & $29.2 \pm 16.7$ & 0.08 \\
Giles & $4.4 \pm 2.2$ & $10.2 \pm 1.9$ & $0.2 \pm 0.2$ & $14.9 \pm 4.0$ & 0.67 \\
Osage & $11.7 \pm 3.3$ & $3.8 \pm 1.6$ & $14.6 \pm 4.1$ & $30.1 \pm 8.2$ & 0.55 \\
\hline
\end{tabular}

${ }^{\mathrm{z}}$ Alternate bearing index: $I=1 /(\mathrm{n}-1)\left[\left|\left(\mathrm{a}_{2}-\mathrm{a}_{1}\right)\right| /\left(\mathrm{a}_{2}+\mathrm{a}_{1}\right)+\left|\left(\mathrm{a}_{3}-\mathrm{a}_{2}\right)\right| \mid\right.$ $\left(\mathrm{a}_{3}+\mathrm{a}_{2}\right)$ ], where $I$ is the alternate-bearing index, $\mathrm{n}$ is the number of years, and $\mathrm{a}_{1}, \mathrm{a}_{2}$, and $\mathrm{a}_{3}$ are yields of corresponding years (Pearce and Dobersek-Urbanc, 1967). The alternate-bearing index ranges from 0 to 1 ; a higher index indicates more alternate bearing. 
New shoot production was similar among cultivars, shoot types, and years, averaging 1.7 new shoots per 1-year-old branch.

There were significant interactions between year and cultivar affecting the number of flowers per 1-year-old branch, percentage of current shoots flowering, and flower cluster size (Table 2). In 2002, 'Giles' produced more flowers per 1-yearold branch than 'Colby' or 'Osage'. The next year, 'Giles' produced fewer flowers than 'Osage' and 'Peruque' but similar to 'Colby'. In 2004, there were no significant differences among cultivars in the number of flowers per 1-year-old branch.

The percentage of current season shoot flowering was a more sensitive measure of return bloom than flowers per 1-year-old branch (Table 2). 'Giles', the most intense alternate-bearing cultivar (Table 1), had a larger percentage of flowering shoots in 2002 than other cultivars (Table 2). The next year, 'Giles' had the lowest percentage of flowering shoots followed by the highest percentage the next year. 'Peruque', the cultivar with the lowest alternate-bearing index (Table 1), averaged 55\% flowering shoots over the 3 years with considerably less variation from year to year than 'Giles' or 'Osage' (Table 2). 'Colby' averaged 28\% flowering shoots with less variation among years than the two high alternate-bearing cultivars. The low percentage of bearing shoots for 'Colby' reflects its low yield potential relative to other cultivars.

Flower cluster size was similar among cultivars in 2002 (Table 2). However, in 2003 and 2004, flower clusters of 'Giles' were smaller than the other cultivars. Cluster size of 'Peruque', 'Colby', and 'Osage' was similar among years, except during 1 year when 'Colby' clusters were larger than 'Osage'.

Significant interactions between cultivar and shoot type were observed for the number of flowers produced per 1-year-old branch, percentage of current season shoots with flowers, and flower cluster size (Table 3). Bearing shoots in the lateral position usually produced fewer flowers per 1-year-old branch and among the lowest percentage of current season shoots flowering. The greatest number of flowers per 1-year-old branch

Table 2. The influence of pecan cultivar and year on return bloom and flower cluster size ${ }^{z}$.

\begin{tabular}{llccc}
\hline Yr & Cultivar & $\begin{array}{c}\text { Flowers per } \\
\text { 1-yr-old } \\
\text { branch (no.) }\end{array}$ & $\begin{array}{c}\text { Current season } \\
\text { shoots } \\
\text { flowering (\%) }\end{array}$ & $\begin{array}{c}\text { Cluster size } \\
\text { (flowers/cluster) }\end{array}$ \\
\hline 2002 & Colby & 1.1 & 23.8 & 3.1 \\
& Peruque & 2.2 & 44.2 & 3.1 \\
& Giles & 3.8 & 66.4 & 3.1 \\
2003 & Osage & 1.6 & 35.0 & 2.9 \\
& Colby & 1.9 & 21.3 & 3.5 \\
& Peruque & 5.1 & 75.6 & 3.7 \\
2004 & Giles & 0.5 & 11.9 & 2.9 \\
& Osage & 4.7 & 67.1 & 3.7 \\
& Colby & 2.1 & 40.1 & 3.8 \\
& Peruque & 1.6 & 46.4 & 3.4 \\
Giles & 2.1 & 56.5 & 2.3 \\
LSD $_{0.05}$ year for the same cultivar & & 1.3 & 18.5 & 3.1 \\
LSD $_{0.05}$ cultivar for the same & & 4.4 & 0.3 \\
or different year $^{\mathrm{y}}$ & 1.6 & & \\
& Osage & & 4.9 & 0.3
\end{tabular}

${ }^{\mathrm{z}}$ Data are pooled over shoot type.

${ }^{\mathrm{y}}$ Least significant difference value at the $5 \%$ level for comparing among years for the same cultivar.

${ }^{\mathrm{x}}$ Least significant difference value at the $5 \%$ level for comparing among cultivars for the same or different year. and percentage of current season flowering shoots occurred on shoots in the terminal position that had borne fruit the previous year for 'Colby' and 'Peruque', cultivars with low alternatebearing tendencies. Vegetative shoots of 'Giles', the most alternate-bearing cultivar in the study, produced more flowers and a larger percentage of flowering shoots than the other shoot types. 'Osage', the other alternate-bearing cultivar, also produced more flowers from previously vegetative shoots than other shoot types. Alternate-bearing tendency may be closely related to the ability of a bearing shoot to produce flowers the next year. The tendency of previously bearing shoots to flower the next year may be closely linked to genotype.

Cluster size was unaffected by shoot type on the cultivars Colby and Giles. Previously, vegetative shoots produced shoots with larger flower clusters than the other shoot types on 'Peruque' and 'Osage'. The larger cluster size produced from previously vegetative shoots of these cultivars was probably related to more vigorous shoots (Dodge and Crane, 1933).

There were no interactions between cultivar and year affecting root $\mathrm{N}$ or $\mathrm{K}$ concentrations during January (data not shown). Organically bound $\mathrm{N}$ in shoots during January was lower in 'Giles' than the other cultivars in 2002 (Table 4). The 2001 crop load was less on 'Giles' than the other cultivars (Table 1), suggesting that crop load did not deplete available N. 'Osage' had the highest shoot N concentration in Jan. 2002 (Table 4) but had among the lowest number of flowers per 1 -year-old branch and second lowest percentage of current season shoots flowering the next spring. In 2003, shoot $\mathrm{N}$ concentration was similar among cultivars, although $\mathrm{N}$ concentrations were less than in 2002 or 2004 (Table 4). In 2004, 'Osage' had the lowest shoot $\mathrm{N}$ concentration and 'Peruque' the highest. These $\mathrm{N}$ concentrations were not closely related to previous crop load because 'Osage' had the largest crop in 2003 and 'Peruque' had the second largest crop (Table 1).

Potassium concentration in the shoots during January was lowest in 'Giles' and highest in 'Peruque' in 2002 (Table 4). These concentrations were apparently not related to the previous crop load (Table 1). In 2003, shoot $\mathrm{K}$ concentration was lowest in 'Colby' and highest in 'Peruque' (Table 4). The next year, 'Osage' had the lowest and 'Peruque' the highest $\mathrm{K}$ concentration. The differences among cultivars and years did not appear closely related to previous season crop load nor alternate-bearing intensity (Table 1).

Shoot $\mathrm{N}$ concentration was similar among years for the three shoot types (data not shown), but there was a significant interaction affecting shoot $\mathrm{K}$ concentration (Table 5). During each year, vegetative shoots had a lower $\mathrm{K}$ concentration than fruit-bearing shoots. Differences in $\mathrm{K}$ concentration between the two bearing shoots were inconsistent among years.

There were no significant differences among cultivars in nonstructural carbohydrate concentration in roots less than $1 \mathrm{~cm}$ diameter [average: starch $1.86 \%$ dry weight (DW), nonreducing sugar $7.42 \% \mathrm{DW}$, reducing sugar $8.68 \%$ DW] and $1 \mathrm{~cm}$ or greater diameter (average: starch $4.46 \% \mathrm{DW}$, 
Table 3. The influence of pecan cultivar and previous year's shoot type on return bloom and flower cluster size ${ }^{\mathrm{z}}$.

\begin{tabular}{|c|c|c|c|c|}
\hline Cultivar & Previous yr's shoot type & $\begin{array}{c}\text { Flowers per } \\
1 \text {-yr-old } \\
\text { branch (no.) }\end{array}$ & $\begin{array}{c}\text { Current season } \\
\text { shoots } \\
\text { flowering }(\%)\end{array}$ & $\begin{array}{c}\text { Cluster size } \\
\text { (flowers/cluster) }\end{array}$ \\
\hline \multirow[t]{3}{*}{ Colby } & Vegetative & 1.6 & 28.5 & 3.4 \\
\hline & Fruiting, terminal position & 2.0 & 31.7 & 3.6 \\
\hline & Fruiting, lateral position & 1.5 & 34.3 & 3.4 \\
\hline \multirow[t]{3}{*}{ Peruque } & Vegetative & 3.1 & 54.9 & 3.7 \\
\hline & Fruiting, terminal position & 3.5 & 61.4 & 3.5 \\
\hline & Fruiting, lateral position & 2.5 & 53.3 & 3.3 \\
\hline \multirow[t]{3}{*}{ Giles } & Vegetative & 2.8 & 53.5 & 2.9 \\
\hline & Fruiting, terminal position & 2.0 & 45.7 & 2.6 \\
\hline & Fruiting, lateral position & 1.3 & 36.5 & 2.7 \\
\hline \multirow[t]{3}{*}{ Osage } & Vegetative & 3.1 & 44.8 & 3.8 \\
\hline & Fruiting, terminal position & 1.8 & 44.7 & 3.2 \\
\hline & Fruiting, lateral position & 1.7 & 43.7 & 3.1 \\
\hline \multicolumn{2}{|c|}{$\mathrm{LSD}_{0.05}$ shoot type for the same cultivar ${ }^{\mathrm{y}}$} & 0.2 & 4.4 & 0.3 \\
\hline \multicolumn{2}{|c|}{$\begin{array}{l}\mathrm{LSD}_{0.05} \text { cultivar for the same or } \\
\text { different shoot type }\end{array}$} & 0.3 & 4.9 & 0.3 \\
\hline
\end{tabular}

${ }^{\mathrm{z}}$ Data are pooled over 3 years.

${ }^{y}$ Least significant difference value at the $5 \%$ level for comparing among shoot types for the same cultivar.

${ }^{\mathrm{x}}$ Least significant difference value at the $5 \%$ level for comparing among cultivars for the same or different shoot type. total nonstructural carbohydrate concentration during 1 year, the lowest another year, and the other year the concentration was the same as in fruiting terminal shoots (Table 6). Bearing lateral shoots had lower total nonstructural carbohydrate concentrations than bearing terminal shoots in 2 of 3 years. Total nonstructural carbohydrate concentration tended to be higher in 2003 and 2004 than in 2002 .

A significant cultivar by year interaction was found for starch concentration in shoots but not for the other nonstructural carbohydrates or total nonstructural carbohydrates in shoots (data not shown). Starch concentration was highest in 'Giles' during 2002 (1.02\% DW) followed by 'Colby' and 'Peruque', and 'Osage' had the lowest concentration of starch $(0.53 \%$ DW). The next year, all cultivars had a similar starch concentration, averaging $0.37 \%$ DW. In 2004, the starch concentration in shoots of 'Colby', 'Peruque', and 'Giles' was similar $(\bar{x}=0.81 \%$ DW), but 'Osage' had a lower starch concentration $(0.67 \% \mathrm{DW})$. nonreducing sugar $7.29 \% \mathrm{DW}$, reducing sugar $6.87 \% \mathrm{DW}$ ). Others have reported nonstructural carbohydrates stored in the roots, and particularly starch, may be related to alternate bearing (Malstrom, 1974; Smith and Waugh, 1938; Wood, 1989, 1991; Worley, 1979a, 1979b). These data do not support that relationship.

A significant year by previous season's shoot type interaction was detected for nonstructural carbohydrate concentrations in shoots during January. Vegetative shoots had the highest

Table 4. The influence of pecan cultivar and year on $\mathrm{N}$ and $\mathrm{K}$ concentrations in shoots during January ${ }^{z}$.

\begin{tabular}{|c|c|c|c|}
\hline \multirow[b]{2}{*}{$\mathrm{Yr}$} & \multirow[b]{2}{*}{ Cultivar } & \multicolumn{2}{|c|}{$\begin{array}{l}\text { Elemental concn } \\
(\% \text { dry wt })\end{array}$} \\
\hline & & $\mathrm{N}$ & K \\
\hline \multirow[t]{4}{*}{2002} & Colby & 1.02 & 0.51 \\
\hline & Peruque & 1.01 & 0.62 \\
\hline & Giles & 0.98 & 0.44 \\
\hline & Osage & 1.12 & 0.58 \\
\hline \multirow[t]{4}{*}{2003} & Colby & 0.85 & 0.39 \\
\hline & Peruque & 0.85 & 0.53 \\
\hline & Giles & 0.86 & 0.46 \\
\hline & Osage & 0.84 & 0.46 \\
\hline \multirow[t]{4}{*}{2004} & Colby & 0.90 & 0.50 \\
\hline & Peruque & 0.96 & 0.59 \\
\hline & Giles & 0.90 & 0.51 \\
\hline & Osage & 0.85 & 0.47 \\
\hline \multirow{2}{*}{\multicolumn{2}{|c|}{$\begin{array}{l}\mathrm{LSD}_{0.05} \text { year for the same cultivar } \\
\mathrm{LSD}_{0.05} \text { cultivar for the same } \\
\text { or different year }\end{array}$}} & 0.02 & 0.02 \\
\hline & & 0.02 & 0.02 \\
\hline
\end{tabular}

${ }^{\mathrm{z}}$ Data are pooled over shoot type.

${ }^{y}$ Least significant difference value at the 5\% level for comparing among years for the same cultivar.

${ }^{x}$ Least significant difference value at the $5 \%$ level for comparing among cultivars for the same or different year.

\section{Discussion}

Production stability among years was greater for 'Colby' and 'Peruque' than 'Giles' and 'Osage' (Table 1). Data suggest that greater production consistency of 'Colby' and 'Peruque' may be associated with little or no inhibition by fruit of return bloom on bearing terminal shoots (Table 3). For example, previous season bearing terminal shoots of 'Colby' and 'Peruque' produced more flowers and flowering current season shoots than shoots that had been vegetative, whereas previous season vegetative shoots of 'Giles' produced more flowers and flowering current season shoots than bearing terminal shoots the next year. 'Osage' production was more consistent than 'Giles' but less consistent than 'Colby' and 'Peruque'. Previous season vegetative shoots of 'Osage' had more flowers than bearing terminal shoots but a similar number of flowering current season shoots.

Return bloom of 'Giles' and 'Osage' bearing lateral shoots appeared to be inhibited more by developing fruit than the low

Table 5. The influence of pecan shoot type and year on K concentrations in shoots during January ${ }^{z}$.

\begin{tabular}{llll}
\hline & \multicolumn{3}{c}{ Potassium concn (\% dry wt) } \\
\cline { 2 - 4 } Previous yr's shoot type & 2002 & 2003 & 2004 \\
\hline Vegetative & 0.47 & 0.42 & 0.40 \\
Fruiting, terminal position & 0.56 & 0.50 & 0.54 \\
Fruiting, lateral position & 0.58 & 0.45 & 0.61 \\
LSD $_{0.05}$ year for same shoot type & \multicolumn{3}{l}{} \\
LSD $_{0.05}$ shoot type for the same of different year & & 0.02 \\
&
\end{tabular}

${ }^{\mathrm{z}}$ Data are pooled over cultivar.

${ }^{y}$ Least significant difference value at the 5\% level for comparing among years for the same shoot type.

${ }^{x}$ Least significant difference value at the 5\% level for comparing among shoot types for the same or different year. 
Table 6. The influence of previous year's shoot type and year on nonstructural carbohydrate concentration in pecan shoots during January ${ }^{z}$.

\begin{tabular}{llcccc}
\hline & & \multicolumn{3}{c}{ Nonstructural carbohydrate concn (\% dry wt) } \\
\cline { 3 - 6 } Yr & Previous yr's shoot type & Starch & sugar & $\begin{array}{c}\text { Reducing } \\
\text { sugar }\end{array}$ & $\begin{array}{c}\text { Total nonstructural } \\
\text { carbohydrates }\end{array}$ \\
\hline 2002 & Vegetative & 1.12 & 7.07 & 5.58 & 13.78 \\
& Fruiting, terminal position & 0.94 & 9.96 & 2.87 & 13.78 \\
& Fruiting, lateral position & 0.33 & 4.62 & 5.47 & 10.42 \\
2003 & Vegetative & 0.26 & 7.34 & 5.07 & 12.67 \\
& Fruiting, terminal position & 0.62 & 6.92 & 8.92 & 16.45 \\
& Fruiting, lateral position & 0.23 & 7.90 & 6.21 & 14.34 \\
2004 & Vegetative & 0.95 & 7.38 & 8.72 & 17.05 \\
& Fruiting, terminal position & 0.82 & 5.12 & 6.80 & 12.74 \\
& Fruiting, lateral position & 0.59 & 7.17 & 6.29 & 14.06 \\
LSD $_{0.05}$ year for same shoot type & 0.06 & 0.41 & 0.31 & 0.56 \\
LSD $_{0.05}$ shoot type for the same or & & & & \\
different year $^{\mathrm{y}}$ & 0.08 & 0.43 & 0.34 & 0.63 \\
\hline
\end{tabular}

${ }^{\mathrm{z}}$ Data are pooled over cultivars.

${ }^{y}$ Least significant difference value at the $5 \%$ level for comparing among years for the same shoot type.

${ }^{x}$ Least significant difference value at the 5\% level for comparing among shoot types for the same or different year.

to moderate alternate-bearing cultivars (Table 3). Previous season bearing lateral shoots of 'Giles' produced 53\% fewer flowers and $32 \%$ less flowering shoots than previous season vegetative shoots. 'Osage' produced $45 \%$ less flowers and $2 \%$ fewer fruiting shoots from the previous season's bearing lateral shoots compared with vegetative shoots. The other two cultivars averaged $15 \%$ flower reduction and $5 \%$ increase in flowering shoots from the previous season's bearing lateral shoots compared with vegetative shoots. Others reported that shoots supporting fruit had less return bloom than vegetative shoots (Malstrom and McMeans, 1982; Smith et al., 1986). These studies apparently used cultivars with relatively strong alternate-bearing tendencies. Also, results of these studies were confounded because shoot position (terminal versus lateral) was not taken into account. Shoot position markedly affects return bloom (Rohla et al., 2006; Smith et al., 2006).

In certain alternate-bearing fruit crops, $\mathrm{N}$ reserves have been proportional to the previous season's crop load (Rosecrance et al., 1996, 1998). This has led scientists to speculate that large crops of pecans may limit subsequent production (Goff et al., 2001; Kraimer et al., 2004; Wood, 2001). However, neither $\mathrm{N}$ nor $\mathrm{K}$ concentrations in the roots were affected by crop load or year (data not shown), although there were differences in the alternate-bearing index and return bloom of the cultivars. Similarly, shoot N and K concentrations did not appear to fluctuate with crop load or return bloom. Other studies found little relation between fall-applied $\mathrm{N}$ and return bloom or yield (Acuña-Maldonado et al., 2003; Smith et al., 2004). Developing pecan fruit appear to place little stress on tree $\mathrm{N}$ reserves because little is removed by the crop (Acuña-Maldonado et al., 2003; Kraimer et al., 2004; Smith et al., 2004).

Nonstructural carbohydrate concentration, and particularly starch concentration, in the roots has been linked to bearing consistency (Malstrom, 1974; Smith and Waugh, 1938; Wood, 1989, 1991; Worley, 1979a, 1979b). However, we found no differences in the concentrations of starch, reducing sugar, nonreducing sugar, or total nonstructural carbohydrates in large or small roots of pecan (data not shown). Similar results have been reported previously (Rohla et al., 2006; Smith et al., 2006). Nonstructural carbohydrate concentrations in shoots were not significantly different among cultivars. Shoot type affected nonstructural carbohydrate concentration; however, there was no apparent relationship to subsequent flowering. Others reported no relationship between shoot carbohydrate concentration and return bloom (Rohla et al., 2006; Smith et al., 1986, 2006; Worley, 1979a, 1979b).

Crop load undoubtedly affects return bloom (Smith and Gallott, 1990); however, the inhibition, at least on certain cultivars, appears to be a general tree-wide reduction in flowering rather than a specific inhibition of bearing shoots by a developing fruit as shown by 'Colby' and 'Peruque' in this study. In another study, return bloom of individual bearing shoots of 'Pawnee' was relatively insensitive to cluster size (Rohla et al., 2005), although subsequent flowering of 'Pawnee' was suppressed by previous production (Smith et al., 2006). Also, similar to results in this study, bearing terminal 'Pawnee' shoots had a greater return bloom than vegetative shoots if the crop load was not excessive (Rohla et al., 2006).

A general reduction in return bloom associated with crop load seems to support the concept that the crop depletes a critical item(s) needed for pistillate flower development the next year. Nonstructural carbohydrates were proposed as a likely candidate (Barnett and Mielke, 1981; Malstrom, 1974; Sparks, 1974, 1975, 1979, 1986; Wood, 1989, 1991, 1995; Wood et al., 2003; Worley, 1979a, 1979b); however, this study and others (Rohla et al., 2005, 2006; Smith et al., 2006; Sparks, 2000,2003 ) found that nonstructural carbohydrate concentrations were not closely associated with return bloom. Furthermore, in well-managed, young 'Pawnee' trees, crop load was not associated with subsequent stored carbohydrate concentrations (Smith et al., 2006). It appears unlikely that nonstructural carbohydrate concentrations play a major role in regulating alternate bearing.

The same scenario is true for $\mathrm{N}$ reserves as nonstructural carbohydrates. In this study, $\mathrm{N}$ concentration in roots or shoots was not closely associated with return bloom. In another study, abundant $\mathrm{N}$ supplied throughout the growing season in irrigation water did not prevent pecan alternate bearing (Rohla et al., 2006). Also, fall-applied $\mathrm{N}$ either did not affect subsequent yield or suppressed yield (Acuña-Maldonado et al., 2003; Smith et al., 2004).

This study indicates that return bloom of shoots with fruit was suppressed in the most alternate-bearing cultivars, 'Giles' and 'Osage'. However, in the least alternate-bearing cultivars, 'Peruque' and 'Colby', fruit did not suppress return bloom on that shoot. Both low and high alternate-bearing cultivars appear to be sensitive to crop overloads causing a general reduction in pistillate flowers, regardless of the previous year's shoot type. Alternate bearing should be reduced by selecting genotypes with return bloom on previously bearing shoots similar to bloom on shoots that were vegetative. 


\section{Literature Cited}

Acuña-Maldonado, L.E., M.W. Smith, N.O. Maness, B.S. Cheary, and B.L. Carroll. 2003. Influence of nitrogen application time on nitrogen absorption, partitioning, and yield of pecan. J. Amer. Soc. Hort. Sci. 128:155-162.

Amling, H.J. and K.A. Amling. 1983. Physiological differentiation of pistillate flowers of pecan and cold requirements for their initiation. J. Amer. Soc. Hort. Sci. 108:195-198.

Barnett, J. and E.A. Mielke. 1981. Alternate bearing: A re-evaluation. Pecan South 8:20-23.

Brown, P.H., S.A. Weinbaum, and G.A. Picchioni. 1995. Alternate bearing influences annual nutrient consumption and the total nutrient content of mature pistachio trees. Trees Structure Function 9:158-164.

Conner, P.J. and R.E. Worley. 2000. Alternate bearing intensity of pecan cultivars. HortScience 35:1067-1069.

Diver, S.G. and M.W. Smith. 1984. Influence of fruit development on seasonal elemental concentrations and distribution in fruit and leaves of pecan. Commun. Soil Sci. Plant Anal. 15:619-637.

Dodge, F.H. and H.L. Crane. 1933. Time and duration of growth of several types of shoots in relation to fruiting performance of the pecan. Natl. Pecan Assn. Bul. 32:64-65.

Goff, B., M. Nesbitt, and C. Browne. 2001. Late season fertilization: An exciting new development for the pecan industry. Proc. Southeastern Pecan Growers' Assn. 94:91-93.

Haeder, H.E. 1977. Effects of potassium on phloem loading and transport. Fertilizer use and production of carbohydrates and lipids Proc. Colloq. Intl. Potash Inst. 13:115-121.

Hodge, J.E. and B.T. Hofreiter. 1962. Determination of reducing sugars and carbohydrates, p. 300-394. In: R.L. Whistler and J.L. Wolfrom (eds.). Methods in carbohydrate chemistry. Vol. 1. Academic Press, N.Y.

Horowitz, W. 1980. Official methods of analysis of the association of analytical chemists, p. 15, section 2058. 13th ed. Assn. Offic. Anal. Chemists, Washington, D.C.

Hunter, J.H. and H.E. Hammer. 1956. Relation of oil content of pecan kernels to chemical components of leaves as a measure of nutrient status. Soil Sci. 82:261-269.

Kraimer, R.A., W.C. Lindemann, and E.A. Herrera. 2004. Recovery of late-season N-15-labeled fertilizer applied to pecan. HortScience 39:256-260.

Malstrom, H.L. 1974. The relationship of stored reserves to yield in mature pecan trees. Proc. Western Pecan Conf. 8:65-69.

Malstrom, H.L. and J.L. McMeans. 1982. Shoot length and previous fruiting affect subsequent growth and nut production of 'Moneymaker' pecan. HortScience 17:970-972.

Marschner, H. 1995. Functions of mineral nutrients: Macronutrients., p. 299-312. In: H. Marschner (ed.). Mineral nutrition of higher plants. 2nd ed. Academic Press, San Diego, Calif.

Pearce, S.C. and S. Dobersek-Urbanc. 1967. The management of irregularity in growth and cropping. J. Hort. Sci. 42:295-305.

Picchioni, G.A., P.H. Brown, S.A. Weinbaum, and T.T. Muraoka. 1997. Macronutrient allocation to leaves and fruit of mature, alternate-bearing pistachio trees: Magnitude and seasonal patterns at the whole-canopy level. J. Amer. Soc. Hort. Sci. 122:267-274.

Rohla, C.T., M.W. Smith, and N.O. Maness. 2005. Effects of cluster size and shoot type on characteristics of pecan nuts. HortScience 40:1300-1303.

Rohla, C.T., M.W. Smith, and N.O. Maness. 2007. The influence of cluster thinning on return bloom, nut quality and concentrations of potassium, nitrogen and non-structural carbohydrates. J. Amer. Soc. Hort. Sci. 132:158-165.

Rosecrance, R.C., S.A. Weinbaum, and P.H. Brown. 1996. Assessment of nitrogen, phosphorus, and potassium uptake capacity and root growth in mature alternate-bearing pistachio (Pistacia vera) trees. Tree Physiol. 16:949-956.
Rosecrance, R.C., S.A. Weinbaum, and P.H. Brown. 1998. Alternate bearing affects nitrogen, phosphorus, potassium, and starch storage pools in mature pistachio trees. Ann. Bot. (Lond.) 82:463-470.

Smith, C.L. and J.G. Waugh. 1938. Seasonal variations in the carbohydrate and nitrogen content of roots of bearing pecan trees. J. Agr. Res. 57:449-460.

Smith, M.W., B.L. Carroll, and B.S. Cheary. 2004. Response to pecan to nitrogen rate and nitrogen application time. HortScience 39:1412-1415.

Smith, M.W. and J.C. Gallott. 1990. Mechanical thinning of pecan fruit. HortScience 25:414-416.

Smith, M.W., R.W. McNew, P.L. Ager, and B.C. Cotten. 1986. Seasonal changes in the carbohydrate concentration in pecan shoots and their relationship to flowering. J. Amer. Soc. Hort. Sci. 111: $558-561$.

Smith, M.W., C.T. Rohla, and N.O. Maness. 2007. Correlations of crop load and return bloom with root and shoot concentrations of potassium, nitrogen and non-structural carbohydrates. J. Amer. Soc. Hort. Sci. 132:44-51.

Sparks, D. 1974. The alternate bearing problem in pecans. Northern Nut Growers'. Assn. 47:80-85.

Sparks, D. 1975. Alternate fruit bearing-A review. Pecan South 2(2):44-65.

Sparks, D. 1979. Physiology-Site, growth, flowering, fruiting, and nutrition, p. 211-239. In: R.A. Jaynes (ed.). Nut tree culture in North America. Northern Nut Tree Growers' Assn., Hamden, Conn.

Sparks, D. 1986. Pecan, p. 323-339. In: S.P. Monselise (ed.) CRC handbook of fruit set and development. CRC Press, Boca Raton, Fla. Sparks, D. 2000. Fruit set in pecan, Carya illinoinensis. Acta Hort. 527:35-48.

Sparks, D. 2003. Growth, flowering, and fruiting, p. 273-316. In: D.W. Fulbright (ed.). A guide to nut tree culture in North America. Vol. 1. Northern Nut Tree Growers Assn., Hamden, Conn.

Vreugdenhil, D. 1985. Source-to-sink gradient of potassium in the phloem. Planta 163:238-240.

Weinbaum, S.A., G.A. Picchioni, T.T. Maraoka, P.H. Brown, and L. Ferguson. 1994. Nitrogen usage, accumulations of carbon and nitrogen reserves, and the capacity for labeled fertilizer nitrogen and boron uptake varies during the alternate-bearing cycle in pistachio. J. Amer. Soc. Hort. Sci. 119:925-930.

Wood, B.W. 1984. Influence of paclobutrazol on selected growth and chemical characteristics of young pecan seedling. HortScience 19:837-839.

Wood, B.W. 1989. Pecan production responds to root carbohydrates and rootstock. J. Amer. Soc. Hort. Sci. 114:223-228.

Wood, B.W. 1991. Alternate bearing in pecan, p. 180-190. In: B.W. Wood and J.A. Payne (eds.). Pecan husbandry: Challenges and opportunities. First Natl. Pecan Workshop Proc. U.S. Dept. Agr., Agr. Res. Serv., ARS-96.

Wood, B.W. 1995. Relationship of reproductive and vegetative characteristics of pecan to previous-season fruit development and post ripening foliation period. J. Amer. Soc. Hort. Sci. 120: 635-642.

Wood, B.W. 2001. Managing nitrogen in pecan orchards. Proc. Southeastern Pecan Growers' Assn. 94:153-159.

Wood, B.W. 2003. Pecan production in North America. Southwestern Entomol. (Suppl.) 27:1-19.

Wood, B.W., P.J. Conner, and R.E. Worley. 2003. Relationship of alternate bearing intensity in pecan to fruit and canopy characteristics. HortScience 38:361-366.

Wood, B.W. and J.L. McMeans. 1981. Carbohydrate changes in various organs of bearing and nonbearing pecan trees. J. Amer. Soc. Hort. Sci. 106:758-761.

Worley, R.E. 1979a. Pecan yield, quality, nutlet set, and spring growth as a response of time of fall defoliation. J. Amer. Soc. Hort. Sci. 104:192-194.

Worley, R.E. 1979b. Fall defoliation date and seasonal carbohydrate concentration of pecan wood tissue. J. Amer. Soc. Hort. Sci. 104:195-199. 